\title{
Energy metabolism of the human Fallopian tube
}

\author{
I. A. Brewis ${ }^{1 *}$, R. M. L. Winston ${ }^{2}$ and H. J. Leese ${ }^{1} \dagger$ \\ ${ }^{1}$ Department of Biology, University of York, Heslington, York YO1 5DD, UK, and ${ }^{2}$ Institute of \\ Obstetrics and Gynaecology, Royal Postgraduate Medical School, Hammersmith Hospital, \\ DuCane Road, London WI2 ONN, UK
}

\begin{abstract}
Summary. The consumption of oxygen $\left(Q_{\mathrm{O}_{2}}\right)$, the production of lactate and the profile of four key metabolic enzymes were measured in small samples of human oviductal mucosa (endosalpinx) removed at surgery. The $Q_{\mathrm{O}_{2}}$ in the absence of substrate was $3.4 \mu \mathrm{l} \mathrm{O}_{2}$ (mg dry wt) ${ }^{-1} \mathrm{~h}^{-1}$, a value typical of quiescent tissue. The $Q_{\mathrm{O}_{2}}$ was stimulated by glucose, but diminished by glutamine and acetoacetate. Tissue lactate production was low and not increased by glucose. Hexokinase had the highest activity of the enzymes measured, followed by 2-oxoglutarate dehydrogenase; 6-phosphofructokinase and glycogen phosphorylase had low activities. The data are consistent with the proposition that glucose is a major metabolic fuel for human endosalpinx.
\end{abstract}

Key'ords: Fallopian tube; oxygen uptake; metabolism; glucose; lactate; human

\section{Introduction}

The human Fallopian tube consists of an outer muscle layer, the myosalpinx, which surrounds an inner mucosal lining, or endosalpinx. This paper reports data on the energy metabolism of the endosalpinx, the two specialized energy-requiring functions of which are the secretion of molecules into oviductal fluid (Leese, 1988) and the mechanical action of cilia.

Endosalpinx from a variety of species including humans is being widely used in the "coculture' of preimplantation embryos (Bongso et al., 1990). Information on the metabolism of the endosalpinx in vitro is likely to be important in defining its role in sustaining embryo development.

Oxygen consumption and lactic acid production by small samples of fimbrial mucosa recovered during tubal microsurgery were measured and the effects of the potential blood-borne respiratory substrates glucose, glutamine and acetoacetate (a ketone body) were examined.

Only two previous studies have measured the oxygen uptake $\left(Q_{\mathrm{O}_{2}}\right)$ of the human Fallopian tube. Mastroianni et al. (1958) reported a $Q_{\mathrm{O}_{2}}$ of $2-3 \mu \mathrm{l} \mathrm{O} \mathrm{O}_{2}(\mathrm{mgdry} \mathrm{wt})^{-1} \mathbf{h}^{-1}$ in endosalpingeal tissue with a suggestion of diminished $Q_{\mathrm{O}_{2}}$ in the isthmus compared with the ampulla. No variation in $Q_{\mathrm{O}_{2}}$ was found during the menstrual cycle. In contrast, Kneer et al. (1952) reported that respiration increased during the follicular phase and decreased during the luteal phase.

There have been no measurements of the activities of key metabolic enzymes in human Fallopian tubes. Newsholme \& Crabtree (1986) showed that the maximum activities of certain nonequilibrium enzymes may provide quantitative information on the metabolic pathways involved in energy provision. Hexokinase activity indicates the maximum capacity of glycolysis from glucose; 6-phosphofructokinase (PFK) and glycogen phosphorylase activities indicate the extent of glycolysis from glycogen; 2-oxoglutarate dehydrogenase activity provides an index of the extent of oxidative metabolism.

*Present address: Department of Biochemistry and Molecular Biology, University of Leeds, Leeds LS2 9JT, UK. tAuthor for correspondence. 
The profile of these enzymes was therefore studied in snap-frozen isthmic and ampullary tissue obtained at abdominal hysterectomy.

\section{Materials and Methods}

\section{Oxygen uptake studies}

Tissue preparation. Small pieces of fimbrial mucosa (2-10 $\mathrm{mg}$ fresh $\mathrm{wt}$ ) were removed during tubal microsurgery performed to treat infertility. We are confident that the precision of the surgical procedures ensured that the samples contained only endosalpinx and no myosalpinx. The samples were washed in a Petri dish containing $0.9 \% \mathrm{NaCl}$ and the experiments conducted in the operating theatre within one minute of tissue removal from the patient. The number of days since the last menstrual period was recorded.

Measurement of $Q_{o}$. Oxygen uptake was measured using a Clark-type oxygen electrode (Rank Bros, Bottisham, Cambridge, UK) connected to a two-pen chart recorder (Data trace: Gallenkamp, Fisons Instrumentation, Crawley, Sussex, UK). A magnetic stirrer was present in the incubation chamber to ensure that the medium was well stirred and that the oxygen requirements of the tissue were satisfied. Each electrode vessel contained $2 \mathrm{ml} \mathrm{Krebs} \mathrm{Henseleit} \mathrm{bicar-}$ bonate buffer, $\mathrm{pH} 7 \cdot 4$, containing $\left.118 \mathrm{mmol} \mathrm{NaCl} 1^{-1}, 25 \mathrm{mmol} \mathrm{NaHCO}_{3}\right]^{\prime}, 4 \cdot 7 \mathrm{mmol} \mathrm{KCl1}^{-1}, 1 \cdot 19 \mathrm{mmol} \mathrm{MgSO}_{4} l^{\prime}$, $1.17 \mathrm{mmol} \mathrm{KH}_{2} \mathrm{PO}_{4} \mathrm{I}^{-1}$ and $1.7 \mathrm{mmol} \mathrm{CaCl} \mathrm{L}^{-1}$ equilibrated with $95 \%$ air $/ 5 \% \mathrm{CO}_{2}$. One of the vessels contained the

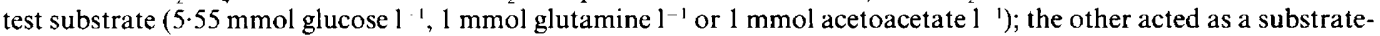
free control. One piece of fimbrial mucosa was placed in each vessel and the oxygen uptake measured for up to $20 \mathrm{~min}$. Values are expressed as $\mu \mathrm{l} \mathrm{O}_{2}$ consumed (mg dry wt) ' $\mathrm{h}$ ' on the basis of a dry wt : fresh wt ratio of $0 \cdot 2(\mathrm{H}$. J. Leese, unpublished observations).

Lactate production. The medium remaining after estimation of oxygen uptake was frozen in dry ice and stored at $-80^{\circ} \mathrm{C}$. The lactate content of thawed samples was measured by the method of Leese \& Bronk (1972).

\section{Enzyme assays}

Tissue preparation. Whole Fallopian tubes were obtained from abdominal hysterectomies performed on women aged $39-45$ years. The tubes were washed in $0.9 \% \mathrm{NaCl}$ to remove surface blood and the isthmus was immediately separated from the ampulla. The tissues were rapidly frozen in liquid nitrogen and stored at $-80^{\circ} \mathrm{C}$ until analysis.

Preparation of homogenates. The frozen ampullary or isthmic segments were thawed and washed briefly in $0.9 \%$ $\mathrm{NaCl}$. The endosalpinx was dissected from the myosalpinx and chopped with a razor blade into four approximately equal samples (each 100-150 mg) and weighed.

Each of the four tissue samples was homogenized in ten volumes of the relevant extraction medium using a Polytron homogenizer (model PCU-2, setting 6: Kinematica, Switzerland) for 1 min at $0^{\circ} \mathrm{C}$. The homogenate was centrifuged for $3 \mathrm{~min}$ at $3000 \mathrm{~g}$ in a microfuge and the resulting supernatant used for enzyme assay. For 2-oxoglutarate dehydrogenase, the crude homogenate was used without further treatment. All reagents were obtained from Sigma (Poole, Dorset, UK).

The extraction medium for hexokinase consisted of $50 \mathrm{mmol} l$ ' triethanolamine $/ \mathrm{HCl}, 1 \mathrm{mmol} \mathrm{EDTA} \mathrm{l}{ }^{-1}, 2 \mathrm{mmol}$ $\mathrm{MgCl}_{2} \mathrm{I}$ ' and $30 \mathrm{mmol}$ mercaptoethanol 1-1, $\mathrm{pH} 7.5$ (Crabtree \& Newsholme, 1972). For 6-phosphofructokinase, the extraction medium contained $50 \mathrm{mmol} \mathrm{KH}_{2} \mathrm{PO}_{4} \mathrm{l}^{-1}, 1 \mathrm{mmol}$ EDTA l ', $100 \mathrm{mmol}\left(\mathrm{NH}_{4}\right)_{2} \mathrm{SO}_{4} 1^{-1}, 1 \mathrm{mmol}$ phenylmethylsulphonyl fluoride $1^{-1}, 30 \mathrm{mmol} \mathrm{KF}^{2}{ }^{1}, 5 \mathrm{mmol}$ mercaptoethanol $1^{-1}$ and $0.02 \%$ bovine serum albumin, $\mathrm{pH} 8.0$ (Jamal \& Kellett, 1983; Chi et al., 1988). 2-Oxoglutarate dehydrogenase was extracted in $250 \mathrm{mmol}$ mannitol 1-1, $5 \mathrm{mmol} \mathrm{N}$-tris(hydroxymethyl)methyl-1-2-aminoethanesulfonic acid $\mathrm{l}^{-1}$ (TES), $1 \mathrm{mmol}$ EGTA 1 ' and 1 mol sucrose $\mathrm{I}^{-1}, \mathrm{pH} 7 \cdot 4$ (Cooney et al., 1981). For glycogen phosphorylase, the extraction medium consisted of $35 \mathrm{mmol}$ giycerol2-phosphate $1^{-1}, 20 \mathrm{mmol} \mathrm{NaFl}^{1}, 1$ mmol EDTA $1^{-1}$ and $30 \mathrm{mmol}$ mercaptoethanol 1 ', $\mathrm{pH} \mathrm{6.2} \mathrm{(Cornblath} \mathrm{et} \mathrm{al.,}$ 1963).

\section{Assay of enzyme activities}

All assays were performed at $25^{\circ} \mathrm{C}$ in a $1 \mathrm{ml}$ cuvette using a recording spectrophotometer (Shimadzu OPI-2, Kyoto, Japan) by measuring the rate of change of absorbance at $340 \mathrm{~nm}$.

Hexokinase. Hexokinase was assayed as the rate of reduction of $\mathrm{NADP}^{+}$in the presence of glucose 6-phosphate dehydrogenase. The assay medium contained $75 \mathrm{mmol}$ Tris $1^{-1}, 7.5 \mathrm{mmol} \mathrm{MgCl}_{2} \mathrm{I}^{-1}, 0.8 \mathrm{mmol}$ EDTA $1^{-1}, 1.5 \mathrm{mmol}$

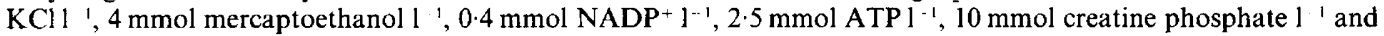
$1 \mathrm{mmol}$ glucose $\mathrm{l}^{-1}, \mathrm{pH} 7 \cdot 5$. Creatine phosphokinase $(100 \mu \mathrm{g})$, glucose 6-phosphate dehydrogenase $(10 \mu \mathrm{g})$ and $20 \mu \mathrm{l}$ hexokinase tissue extract were added to $\mathrm{lml}$ assay medium. Control assays for nonspecific NADP ${ }^{+}$reduction were carried out with the same medium except that glucose was omitted (Crabtree \& Newsholme, 1972).

6-Phosphofructokinase. 6-Phosphofructokinase was assayed by measuring the rate of oxidation of NADH in the presence of aldolase, $\alpha$-glycerophosphate dehydrogenase and triose isomerase phosphate (TIM). The assay medium 
contained $30 \mathrm{mmol}$ Tris/HCl ', $50 \mathrm{mmol} \mathrm{KCl} 1^{-1}, 10 \mathrm{mmol} \mathrm{MgCl}_{2} 1^{-1}, 1 \mathrm{mmol}$ dithiothreitol 1 ', $1 \mathrm{mmol} \mathrm{KCN1}$, $2 \mathrm{mmol}$ ATP ! ' , $50 \mu \mathrm{mol}$ fructose 2,6-bisphosphate $\mathrm{l}^{-1}, 0 \cdot 16 \mathrm{mmol} \mathrm{NADH} \mathrm{l}^{-1}$ and $50 \mathrm{mmol}$ fructose 6-phosphate 1 ', $\mathrm{pH} 8.0$. Aldolase $\left(0.46 \mathrm{U} \mathrm{ml}^{-1}\right)$, TIM/glycerophosphate dehydrogenase $\left(0.78 \mathrm{U} \mathrm{ml}^{-1}\right)$ and $20 \mu 1$ phosphofructokinase tissue extract were added to $1 \mathrm{ml}$ assay medium (Ling et al., 1965; Zammit \& Newsholme, 1976; Jamal \& Kellett, 1983). Control assays contained all the constituents except fructose 6-phosphate.

2-Oxoglutarate dehydrogenase. 2-Oxoglutarate dehydrogenase was assayed as the rate of reduction of $\mathrm{NAD}^{+}$. The assay medium contained $250 \mathrm{mmol}$ mannitol $1^{-1}, 10 \mathrm{mmol} \mathrm{KH_{2 }} \mathrm{PO}_{4} 1^{-1}, 100 \mathrm{mmol}$ Tris $/ \mathrm{HCl}^{-1}, 10 \mathrm{mmol} \mathrm{KCl1^{-1 }}$, $5 \mathrm{mmol} \mathrm{MgCl}, 1^{-1}, 1 \mathrm{mmol}$ dithiothreitol $\mathrm{l}^{-1}, 0.05 \%$ (v/v) Triton X-100, 2 mmol NAD ${ }^{+} 1^{1}, 0.63$ mmol coenzyme Al ${ }^{\prime}$ and $10 \mathrm{mmol} 2$-oxoglutarate $\mathrm{l}^{-1}, \mathrm{pH} 7 \cdot 4$. Crude tissue homogenate $(80 \mu \mathrm{l})$ was added to $1 \mathrm{ml}$ assay mixture (Cooney et al., 1981). In control assays, coenzyme A was omitted.

Glycogen phosphorylase. Glycogen phosphorylase was assayed as the rate of $\mathrm{NADP}^{+}$reduction with phosphoglucomutase and glucose 6-phosphate dehydrogenase. The assay medium contained $45 \mathrm{mmol} \mathrm{KH}_{2} \mathrm{PO}_{4} 1^{-1}, 0 \cdot 1 \mathrm{mmol}$

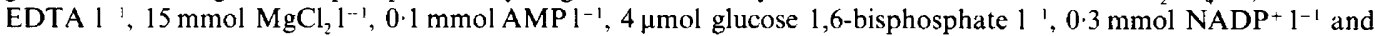
$2 \mathrm{mg} \mathrm{ml}$ ' glycogen at $\mathrm{pH} 6 \cdot 2$. Phosphoglucomutase $\left(0 \cdot 8 \mathrm{U} \mathrm{ml}^{-1}\right)$, glucose 6 -phosphate dehydrogenase $\left(6 \mathrm{U} \mathrm{ml}^{-1}\right)$ and $50 \mu \mathrm{l}$ glycogen phosphorylase extract were added to $1 \mathrm{ml}$ assay medium (Bergmeyer, 1983). Glycogen was omitted from the control assays.

All results are expressed as $\mu \mathrm{mol}$ substrate utilized (g fresh wt tissue) ${ }^{-1} \min ^{-1}$ at $25^{\circ} \mathrm{C}$.

\section{Results}

\section{Respiration studies}

Oxygen consumption. Oxygen was consumed linearly for 10-15 min and the rate then gradually declined. A significantly higher oxygen uptake was found in the presence of $5.55 \mathrm{mmol}_{\text {glucose } 1^{-1}}$ $(P<0.05)$ (Fig. 1). In contrast, the presence of $1 \mathrm{mmol}$ glutamine $1^{-1}$ or $1 \mathrm{mmol}$ acetoacetate $1^{-1}$ resulted in significantly lower $Q_{\mathrm{O}_{2}}(P$ values $<0.01$ and $<0.05$, respectively). Measurements at different stages of the menstrual cycle suggested that the $Q_{\mathrm{O}_{2}}$ reached a maximum value at the same time as the peak in plasma oestrogen on days 11-12 of the cycle, but the variation in the data precluded a definite conclusion.

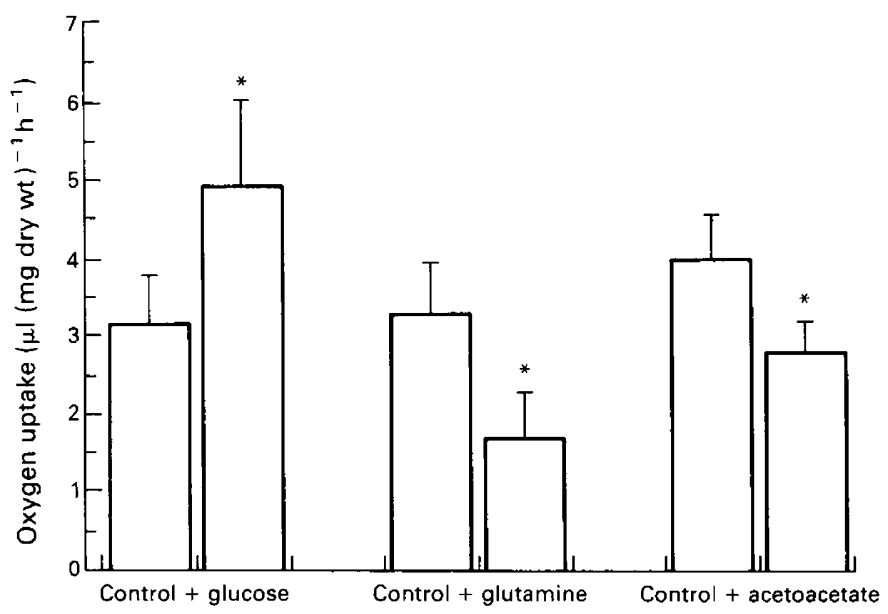

Fig. 1. Effect of $5.55 \mathrm{mmol}$ glucose $1^{-1}(n=8), 1 \mathrm{mmol}$ glutamine $1^{-1}(n=6)$ and $1 \mathrm{mmol}$ acetoacetate $1^{-1}(n=5)$ on oxygen consumption of human endosalpinx. Values are means \pm SEM.

*Significantly different $(P<0.05)$ from control using paired $t$-tests based on the differences for each patient. 


\section{Lactate production}

Lactate was released into the medium in the absence of substrate (Fig. 2) and the amount did not increase significantly in the presence of glucose, glutamine or acetoacetate.

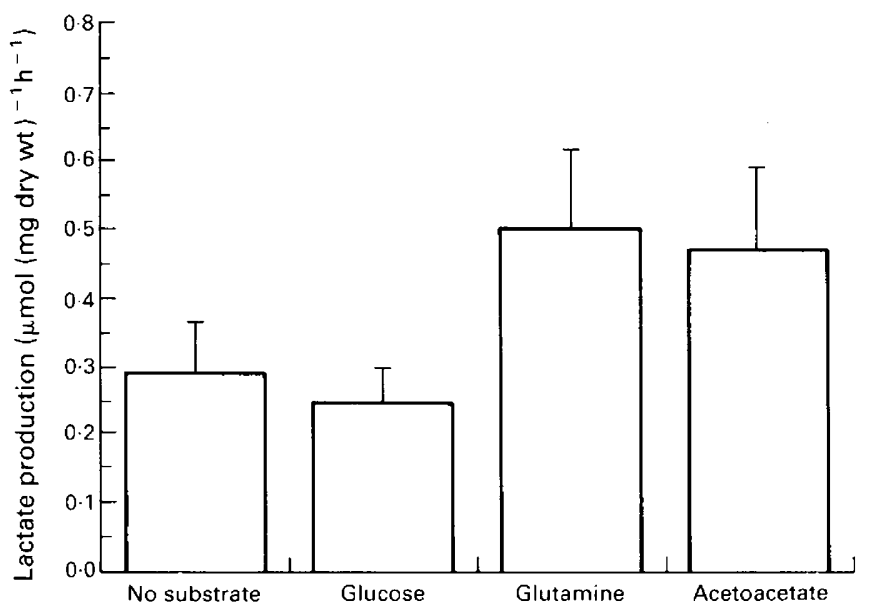

Fig. 2. Lactate production by human endosalpinx incubated in the absence of substrate $(n=4)$, and in the presence of $5.55 \mathrm{mmol}$ glucose $1^{-1}(n=8), 1 \mathrm{mmol}$ glutamine $\mathrm{l}^{-1}(n=10)$ and 1 mmol acetoacetate $1^{-1}(n=4)$. Values are means \pm SEM.

\section{Enzyme activities}

Preliminary experiments were performed to ensure that the tissue extraction and assay procedures gave optimal rates of activity for each enzyme.

Hexokinase had the highest activity, followed by 2-oxoglutarate dehydrogenase (Table 1); PFK and glycogen phosphorylase had low activities. There was no significant difference between ampullary and isthmic mucosa.

Table 1. Maximal activities of key metabolic enzymes in human endosalpinx

\begin{tabular}{|c|c|c|}
\hline Enzyme & $\begin{array}{c}\text { Ampullary mucosa } \\
\mu \mathrm{mol}(\mathrm{g} \text { fresh } \mathrm{wt})^{\prime} \mathrm{min}{ }^{-1}\end{array}$ & $\begin{array}{c}\text { Isthmic mucosa } \\
\mu \mathrm{mol}(\mathrm{g} \text { fresh } \mathrm{wt})^{\prime} \mathrm{min}\end{array}$ \\
\hline Hexokinase & $0 \cdot 86 \pm 0 \cdot 12$ & $0.58 \pm 0.09$ \\
\hline Phosphofructokinase & $0.12 \pm 0.03$ & $0.10 \pm 0.02$ \\
\hline Glycogen phosphorylase & $0.04 \pm 0.02$ & $0.05 \pm 0.02$ \\
\hline 2-oxoglutarate dehydrogenase & $0.35 \pm 0.08$ & $0.21 \pm 0.03$ \\
\hline
\end{tabular}

Values are means \pm SEM of six (ampulla) and five (isthmus) determinations.

\section{Discussion}

These studies on the metabolism of the human Fallopian tube provide a reliable indication of oxygen consumption, lactate formation and enzyme content of the endosalpinx. The tissue samples were small and thin. The anoxic interval between excision of the tissue and measurement of its 
respiration was kept to less than $1 \mathrm{~min}$ and oxygen was consumed linearly throughout the experiments. Tissue for the determination of enzyme activities was frozen rapidly after removal from patients and extracted in media appropriate for each enzyme.

In the absence of exogenous substrate, the mean $Q_{\mathrm{O}_{2}}$ of isolated fimbrial mucosa was $3.4 \mu \mathrm{l} \mathrm{O}$ (mgdry wt $)^{-1} \mathrm{~h}^{-1}$. This value is similar to that reported by Mastroianni et al. (1958) for human fimbrial endosalpinx $\left(4.0 \mu \mathrm{O}_{2}(\mathrm{mg} \mathrm{dry} \mathrm{wt})^{-1} \mathrm{~h}^{-1}\right)$, but slightly less than that obtained for slices of whole rabbit preampulla $\left(4.8 \mu \mathrm{O}_{2}(\mathrm{mgdry} \mathrm{wt})^{-1} \mathrm{~h}^{-1}\right.$; Leese et al., 1981), which, like fimbrial mucosa, consists predominantly of endo- as opposed to myosalpinx, and for whole segments of mouse ampulla $\left(4.8 \mu \mathrm{O} \mathrm{O}_{2}(\mathrm{mg} \text { dry wt })^{-1} \mathrm{~h}^{-1}\right.$; Edwards \& Leese, unpublished observations). These data indicate that, metabolically, the mammalian endosalpinx is a relatively quiescent tissue. Rat small intestinal mucosa, for example, which bears some anatomical resemblance to the oviductal mucosa, has a $Q_{\mathrm{O}_{2}}$ of about $10 \mu \mathrm{l} \mathrm{O} \mathrm{O}_{2}(\mathrm{mg} \text { dry wt) })^{-1} \mathrm{~h}^{-1}$ (Bronk \& Leese, 1973). Human liver, heart and kidney have $Q_{\mathrm{O}_{2}}$ values of approximately 11,30 and $48 \mu \mathrm{l}(\mathrm{mgdry} \mathrm{wt})^{-1} \mathrm{~h}^{-1}$, respectively (Newsholme \& Leech, 1983).

Of the three nutrients tested, only $5.55 \mathrm{mmol}$ glucose $1^{-1}$ stimulated the $Q_{\mathrm{O}_{2}}$, while glutamine and acetoacetate were inhibitory. This suggests that glucose is a potential blood-borne respiratory substrate for the endosalpinx. This conclusion is supported by the data on lactate formation and enzyme activities.

Lactate appeared in the medium in the absence of substrate. This could represent the wash-out of pre-existing tissue lactate or its formation from endogenous glycogen (Arrata \& Arronet, 1971) or traces of contaminating blood glucose. Significantly, the addition of glucose failed to increase lactate output, suggesting that the fate of this sugar in the endosalpinx is complete oxidation. The relatively high activity of hexokinase is consistent with this suggestion.

The quotient:

$18 \times$ maximal activities of 2 -oxoglutarate dehydrogenase $\div 3 \times$ maximal activity of 6-phosphofructokinase

provides a guide to the potential of a tissue to produce ATP by oxidative metabolism as opposed to glycolysis (Newsholme et al., 1980; Blomstrand et al., 1983; Newsholme \& Crabtree, 1986). The values for endosalpinx from the ampulla and isthmus are 17 and 13 , respectively, in good agreement with the data on oxygen uptake and lactate production, and strongly suggest that the energy needs of the human endosalpinx are largely served by the oxidation of glucose.

Control of glucose metabolism probably resides at the level of 6-phosphofructokinase. Calculation shows that the oxygen consumption in the presence of glucose $\left(4.9 \mu \mathrm{O} \mathrm{O}_{2}(\mathrm{mg} \mathrm{dry} \mathrm{wt})^{-1} \mathrm{~h}^{-1}\right)$ is equivalent to the oxidation of about $0.13 \mu \mathrm{mol}$ glucose $\min ^{-1}$ ( $\mathrm{g}$ fresh tissue ${ }^{-1}$ ). This value is remarkably close to the maximal activity of 6-phosphofructokinase $\left(0.12\right.$ and $0.10 \mu \mathrm{mol} \mathrm{min}^{-1}$ ( $\mathrm{g}$ fresh $\mathrm{wt})^{-1}$ for mucosa from ampulla and isthmus, respectively). While such an agreement is to some extent probably coincidental, it is consistent with the general pattern described.

We thank Mr D. Pring (York District Hospital) who performed the abdominal hysterectomies and The Wellcome Trust for a research grant.

\section{References}

Arrata, W.J.W. \& Arronet, G.H. (1971) Glycogen metabolism of the human endosalpinx and endometrium. International Journal of Gynaecology and Obstetrics 9, 210-216.

Bergmeyer, H.-U. (1983) In Methods of Enzymatic Analysis (3rd edn) vol. II, pp. 293-295. Verlag Chemie, Weinheim.

Blomstrand, E., Challiss, J., Cooney, G.J. \& Newsholme, E.A. (1983) Maximal activities of hexokinase, 6- phosphofructokinase, oxoglutarate dehydrogenase and carnitine palmitoyltransferase in rat and avian muscles. Bioscience Reports 3, 1149-1153.

Bongso, A., Ng, S.-C. \& Ratnam, S. (1990) Co-cultures: their relevance to assisted reproduction. Human Reproduction 5, 893-900.

Bronk, J.R. \& Leese, H.J. (1973) Changes in the adenine nucleotide content of preparations of the rat small intestine in vitro. Journal of Physiology 235, 183-196. 
Chi, M.M.-Y., Manchester, J.K., Yang, V.C., Curato, A.D., Strickler, R.C. \& Lowry, O.H. (1988) Contrast in levels of metabolic enzymes in human and mouse ova. Biology of Reproduction 39, 295-307.

Cooney, G.J., Taegtmeyer, H. \& Newsholme, E.A. (1981) Tricarboxylic acid cycle flux and enzyme activities in the isolated working rat heart. Biochemical Journal 200, 701-703.

Cornblath, M., Randle, P.J., Parmeggiani, A. \& Morgan, H.E. (1963) Regulation of glycogenolysis in muscle. Journal of Biological Chemistry 238, 1592-1597.

Crabtree, B. \& Newsholme, E.A. (1972) The activities of phosphorylase, hexokinase, phosphofructokinase and glycerol-3-phosphate dehydrogenase in muscles from vertebrates and invertebrates. Biochemical Journal 126, 49-58.

Jamal, A. \& Kellett, G.L. (1983) The effect of starvation on the control of phosphofructokinase activity in the epithelial cells of the rat small intestine. Biochemical Journal 210, 129-135.

Kneer, M., Burger, H. \& Simmer, H. (1952) Uber die Atmung der Schleimhaut menschlicher Eileiter. Archiv für Gynakologie 181, 561-574.

Leese, H.J. (1988) The formation and function of oviduct fluid. Journal of Reproduction and Fertility 82,843-856.

Leese, H.J. \& Bronk, J.R. (1972) Automated fluorometric analysis of micromolar quantities of ATP, glucose and lactic acid. Analytical Biochemistry 45, 211-221.

Leese, H.J., Humpherson, P.G. \& Jeffries, K.S. (1981) Two preparations for the study of the isolated rabbit oviduct. Journal of Reproduction and Fertility 63, 249-255.

Ling, K.H., Marcus, F. \& Lardy, H.A. (1965) Purification and some properties of rabbit muscle phosphofructokinase. Journal of Biological Chemistry 240, 1893-1899.

Mastroianni, L. Jr, Winternitz, W.W. \& Lowi, N.P. (1958) The in vitro metabolism of the human endosalpinx. Fertility and Sterility 9, 500-509.

Newsholme, E.A. \& Crabtree, B. (1986) Maximum catalytic activity of some key enzyme in the provision of physiologically useful information about metabolic fluxes. Journal of Experimental Zoology 239, 159-167.

Newsholme, E.A. \& Leech, A.R. (1983). Biochemistry for the Medical Sciences. John Wiley \& Sons, Chichester, UK.

Newsholme, E.A., Crabtree, B. \& Zammit, V.A. (1980) Use of enzyme activities as indices of maximum rates of fuel utilisation. CIBA Foundation Symposium 73, 245-258.

Zammit, V.A. \& Newsholme, E.A. (1976) The maximum activities of hexokinase, phosphorylase, phosphofructokinase, glycerol phosphate dehydrogenase, lactate dehydrogenase, octopine dehydrogenase, phosphoenolpyruvate carboxykinase, nucleoside diphosphatekinase, glutamate oxaloacetate transaminase and arginine kinase in relation to carbohydrate utilisation in muscles from marine invertebrates. Biochemical Journal 160, 447-462.

Received 13 March 1991 